\title{
Project-based learning: an analysis of cooperation and evaluation as the axes of its dynamic
}

\author{
Berta de la Torre-Neches (10 ${ }^{1 凶}$, Mariano Rubia-Avi ${ }^{1}$, Jose Luis Aparicio-Herguedas ${ }^{2} \&$ \\ Jairo Rodríguez-Medina (i) ${ }^{3}$
}

Project-based learning is an active method that develops the maximum involvement and participation of students in the learning process. It requires the teacher to energize the learning scenario by promoting the cooperation of students to investigate, make decisions and respond to the challenges of the project. It also requires activating an evaluation system that promotes awareness, reflexivity and a critical spirit, facilitating deeper learning. This case study aims to understand the functioning of cooperative work established during the application of the method, as well as to know how the evaluation process progresses in the perspective of a group of teachers of secondary education that set up this methodology in their classes. The data obtained from interviews with the teachers involved in the study, teachers' notebooks, and open-question questionnaire applied to high-school students are analyzed. Although the students were organized in small groups in order to develop their collaborative skills, intragroup frictions and conflicts were not sufficiently addressed or supervised in time by the teachers, thus resulting in an incomplete development of the synergies and collaboration necessaries to the project. From the point of view of the evaluation, the importance of the implementation of training and shared evaluation systems is well recognized, although a more traditional evaluation model, which does not sufficiently address the project development process prevails, and the value of the qualification on the final product achieved still weights.

\footnotetext{
${ }^{1}$ Department of Pedagogy, Faculty of Education and Social Work, University of Valladolid, Paseo de Belén, 1, 47011 Valladolid, Spain. ${ }^{2}$ Deparment of Physical Education, Faculty of Education, University of Valladolid, Plaza de la Universidad, 1, 40005 Segovia, Spain. ${ }^{3}$ Department of Methods of Research and

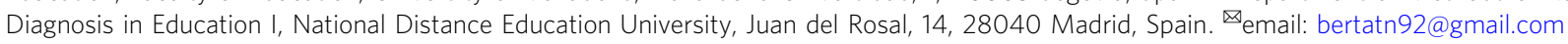




\section{Introduction}

$s$ a result of the crisis scenario that began in Spain in 2007, the need to incorporate to the Secondary Education stage some subjects with economic contents, was posed in order to introduce and make students understand the socio-economic circumstances in the world. Simultaneously, teaching methods have been incorporating some learning methodologies that aim to make students able to solve, with involvement, the problems presented to them (Martín and Rodríguez, 2015). Some of these methods orient learning towards a competitive character such as cooperative methodologies, gamification or project-based learning (PBL) (Hernández March, 2006).

The PBL method is a methodological alternative that involves direct contact with the object of study and ends with the realization of a work project by the students initially proposed by the teacher (Bell, 2010), applying knowledge and skills and developing an attitude of commitment (Sánchez, 2018). In order to do this, students analyze the topic raised, think about it, organize themselves, search for information, work as a team and make decisions. It is, therefore, intended to promote knowledge of the contents as well as the management of skills and attitudes, learning to mobilize those resources said in situation and to solve problems (Perrenoud, 2008).

The experience carried out requires students to face real-life problem statements through activities that suit their interests (Krajcik and Blumenfeld, 2006), find and use tools to address them and act collaboratively to propose solutions through an action plan (Barret, 2005; Bender, 2012; Blumenfeld et al., 1991). Traditional training models are based in the premise that students have to know the content in order to apply it in solving a problem. The PBL reverses this order and considers that students obtain the knowledge while solving a problem (Jonassen, 2011), an aspect that results in a higher quality of the information they handle to solve it, since it is shared, discussed and applied in a concrete situation (Thomas, 2000).

Thus, through PBL, students plan, discuss, and implement projects that have real-world impact and are significant to them (Blank, 1997; Dickinson et al., 1998). They implement skills for the management of interpersonal and team relationships, the teacher acting as a guide and counselor during the learning process (Kolmos, 2012; Thomas, 2000). This allows students to think about their proposals, develop them and become aware of the process itself and everything that it implies beyond the results achieved (Brundiers and Wiek, 2013; García et al., 2010).

In this way, the acquisition of social skills, empathetic behavior, dialog and listening (Belland et al., 2006), the development of critical and reflective thinking (Mergendoller et al., 2006) is favored by activating competencies such as collaboration, decision-making, organization and group responsibility (Blank, 1997; Dickinson et al., 1998), contributing to the development of a more motivating and participatory learning climate (Lima et al., 2007).

This methodological aspect requires, in parallel, the review of the evaluation systems; it appears as necessary to leave behind the traditional cumulative models to introduce a new model of more formative, shared and authentic evaluation that is able to guarantee a greater involvement of the students in the development of their and their peer's learning process (Brown and Race, 2013). An authentic evaluation offers the students opportunities to learn through the evaluation process planned and directed by the teacher. When the evaluation system is carefully designed to articulate with the learning results that are expected to be achieved, it is possible to obtain benefits in terms of greater participation and helps students to advance in the development of their knowledge, skills and attitudes (Brown, 2015).

\section{Cooperation as the basis of project-based learning}

One of the essential aspects of developing the PBL is the management of cooperation between the group participants, an aspect that must be guaranteed and supervised by offering sufficient feedback (Thomas, 2000). For Orlick (1986) cooperation is directly related to communication, cohesion, trust and skills development for positive social interaction.

However, Díaz-Barriga and Hernández (2002) consider that group work, which teachers frequently launch in project initiatives, does not necessarily implies true cooperation and there are many interpersonal problems that students face (Prince and Felder, 2006). This aspect prevents a real learning of collaboration and its application in action to address the shared phase of project management.

Burdett (2007) considers that, sometimes within the group, interpersonal relationships are strained since participation in group work involves much more than each member's knowledge on a given subject: It involves listening, negotiating, giving in; ultimately, skills that favor the dynamics of group work. Such situations of tension and intragroup crises jeopardize the assignment to be developed and the effectiveness of group synergy, as established by Del Canto et al. (2009), Jhen and Mannix (2001), Kerr and Bruun (1983), Putnam (1997), and Velázquez (2013) and those are grouped around five critical dimensions: Differences in individual capacities to complete assignments, resulting in the stowaway effect; imbalance in the functions to be performed; early abandonment in completing assignments due to unresolved discrepancies; struggle to make one's own ideas prevail and lack of communicative skills.

Also for Kerr and Bruun (1983) and Slavin (2014) tensions arise from the lack of a follow-up by the teacher in the group work process entrusted to their students, not monitoring the performance and contribution of each member by thriving the aforementioned stowaway effect, imbalances in workloads borne by each member and unresolved crises in interpersonal relationships, not benefiting the task management, the project development and its fair evaluation.

Intragroup conflicts often cause widespread student complaints, lack of motivation, frustration, and occasionally, a preference for individual work that does seem to guarantee the fair evaluation of the assignment (Gámez and Torres, 2012; McConnell, 2005).

That is why establishing initial cooperative learning dynamics to learn how to collaborate, assume new responsibilities, communicate and assertively express ideas (Velázquez, 2013), is essential to get started in the PBL methodology. Johnson et al. (1999a) define cooperative learning as a work-based methodology in small, usually heterogeneous groups in which students work together to improve their own and other member's learning.

Several authors understand cooperative learning as an active methodology that favors the reflection of students while completing the assignment; not only des it allow to achieve academic goals, but also social objectives, it stimulates interaction through the proposal of small groups and guides the realization of a type of group work, structured and monitored, to favor the learning of all the members of the group without exception (Dyson, 2002; Johnson et al., 1999b; Kagan, 2000; Pujolàs, 2009).

According to Johnson and Johnson (1999) the management of cooperative learning by teachers requires, for its effectiveness, guarantees in the management of positive interdependence, making the students understand that work benefits colleagues by prioritizing "us" over "I", proactive interaction, individual responsibility, interpersonal skills, and group processing at the end of the work sessions performed. 
The teacher establishes a structured process of true cooperation easing the development of academic objectives, but also other competitive objectives: cooperation, communication, social skills (Walberg and Paik, 2002).

It is important to note in this regard the role of the evaluation on the projects implemented, developed and presented. PérezPueyo and López-Pastor (2017) propose a model of formative evaluation through the use of cooperative projects, in which a further step is taken in the autonomy of the students by fully involving them in the teaching process through shared tutoring, especially when the realization of projects that require a lot of involvement or levels of complexity in their realization is encouraged. In addition, the use of tools such as auto evaluations and group co-evaluations (Hamodi et al., 2015), allow the teacher to give more effective feedback during the process, based on the information provided by the students.

\section{Objectives}

Based on the contributions of the various authors cited above, who understand cooperative learning as an active methodology that allows students to achieve not only academic goals but also social objectives, thus promoting the learning for all the students without exceptions, the present study aims to achieve the following objectives: Understanding the functioning of cooperative work present in the development of the operational dynamics of the PBL launched.

Knowing how the formative evaluation process develops in the operational dynamics of the PBL.

\section{Methods}

Participants and context. The study included 16 students on their fourth year of Secondary Education (with an average of 15 years old, 8 females and 8 males) attending Cristo Rey Polytechnic Institute in the city of Valladolid, and taking the elective subject of Economics. Also three male teachers and two female teachers (ages [35-57]) who teach at the same center and stage, in which they apply PBL as an active methodology. All procedures were in accordance with the ethical standards of the institutional and national research committee and with the 1964 Helsinki declaration and its later amendments or comparable ethical standards.

Procedure. During the development of the research, the ability of students to work through PBL was tested, applying the academic project entitled My Business Plan, throughout the subject of Economics in the compulsory secondary education stage. The students were arranged in groups of 4 to 5 members with different capacities and potentialities.

These heterogeneous groups allowed the development of various skills by the students, with the intention of improving them together with intragroup interpersonal relationships.

Data collection and information analysis tools. An in-depth interview was designed for teachers who were to some extent incorporating PBL as an active methodology in the development of their subjects. They thus form a representation of the faculty imparting subjects such as Economics, Geography and History, Biology and Geology, Physics and Chemistry and Philosophy. At the same time, an open-question questionnaire was designed for students. Finally, a reflexive diary was drafted in which observations were recorded from the experiences carried out in class.

In relation to the analysis of the information obtained, the ATLAS.ti software has been used, confectioning a work of textual analysis of the transcripts of teachers' interviews, the answers on the open questions of the questionnaire answered by the students, alongside with the teacher's own reflexive diary.

On the three primary documents, a coding process is carried out inductively and deductively through two cycles (Miles et al., 2014). Thus, during the process, a constant circular relationship between the codes already obtained and the new ones I created, refining the concepts, grouping them, to infer in higher-level constructs as groups of explanatory codes (Kalpokaite and Radivojevic, 2019).

The codes obtained during the first coding cycle were analyzed critically and independently by the four researchers participating in the study establishing a thoughtful debate. Continuous feedback between researchers and their ongoing participation in the regeneration and refinement of codes and groups of codes supported the credibility, reliability and transparency of the research (Neal et al., 2015).

It was considered that saturation had been reached at the time where comparisons between the data ceased to show new relationships and properties between them, depleting that representative wealth of a circular analytical process (Flick, 2007).

In order to address the credibility aspects of the research in relation to the interpretative difficulties of the phenomenon studied (Lincoln and Guba, 1985), a structure of prolonged over time experimentation was developed, with the presence of the researcher at the location, maintaining the same methodological order, establishing her figure as an observer teacher during the time of research; in the analysis of the data, a process of triangulation was developed from the three aforementioned sources of documentary data, this allowing the contrast of the discoveries.

\section{Results}

Forty-one explanatory codes of the phenomenon under investigation were established and grouped around four categories: Learning, interaction-collaboration, motivation, organization.

The use of the ATLAS.ti software as a code co-coordinate tool was convenient, allowing to observe how four codes of the categories Learning and Interaction-Collaboration related to each other: cooperation, conflicts, evaluation and project. Their relational study allows to reflect critically on the several handicaps found and whose consideration is essential for the applicability of the practice.

Thus, to address the first objective of the study-knowing the functioning of cooperative work in the development of the operational dynamics of the PBL launched-taking as a starting point the perceptions of the teachers interviewed and the relationships they establish between PBL and cooperation, they show a formula of practical application using cooperative structures in the form of small groups, which they consider makes it easier for students to encourage communication, to develop skills for interpersonal relationships, as well as individual and group responsibility in the fulfillment of the assignments proposed.

(...) I mix it at first with cooperative work, with small groups, with cooperative structures because being such dense subjects (...) and at the end of the school year, the last quarter, we already work on the project (Male Teaching Interview. 4:69).

In the groups, the smaller the better they work, (I would recommend) four tops, like last year (...) this allows everyone to work, if they are too many, the tasks get diluted and if there are very few, and it also happens sometimes, if one is sick or misses class for some reason for too many days, the groups gets resented... then it rally allows to work on relationships and influences the quality of learning very 
clearly by what I say... one is good at one thing, the other is good at some other thing, and they end up learning from each other (Male Teaching Interview. 4:358).

The same teacher considers, in the application of the methodology, the creation of small working groups, defending this formula as very valuable to develop the communicative and negotiation abilities to reach agreements and coordinate with others, the students winning from an experiential point of view, in socialization and interaction resources.

I divided the class into 4 groups of 4 students each (...), they had ten minutes to explain in front of the rest of the classmates what their business model was by answering various questions. (...) the idea of the project is that they are the ones who work on this concept throughout the course and thus gradually become familiar with that environment and its vocabulary (Reflexive Diary. 3:394).

Through the PBL they work together, they talk more, they must agree on different aspects, and it requires coordination, that is, an effort of all of them, not depending so much on their individual abilities; this approach is very different from the master class, and I do believe that, from a social point of view, socialization develops more and better this way (Reflexive Diary. 4:412).

However, the same teachers interviewed acknowledge that, during the development of the methodology, applying group work strategies for cooperation, numerous frictions and interpersonal conflicts are often triggered within the working groups. A closer attention is put on those students who does not follow the intended pattern of behavior and unleash conflict because they do not assume or carry out their workload.

The most negative aspect are those students who do not want to participate, or find it difficult to participate, or do not get involved and seriously harm the group, and sometimes problems such as friction and conflicts can appear among them for this reason; working individually, logically, there is no such problem (Female Teacher Interview. 4:150).

That student who is a little lazier, they can take advantage of the group work situation so that others work a little for them (Male teacher interview. 4:343).

This aspect is also observed and recorded by the teacher in her reflexive diary, acknowledging incidents that are likely to occur in the groups, generating some interpersonal conflict and influence on group performance to carry out the tasks of the project.

There is a group of four boys who you have to tell off and who I do not intend to bring together in the future for the groups of the project (Reflexive Diary. 3:296).

Z (...) during group work he plays with the table, gets distracted by what other teammates do (...). I think he's a boy who is too easily distracted and annoys his peers (Reflexive Diary. 3:160).

The students themselves consider that the project suffers when situations in which not all members of the group work in tune occur, creating imbalances in the effort made and in the management of the workloads and involvement assumed, which have an impact not only on the realization of the tasks and assignments and their final evaluation, but also on the intragroup climate.
I don't like it when there's someone in my group who doesn't work and gets the same grade as me or we fail the project all because of him, because we don't all work equally; sometimes I felt that if I didn't tell them to do something, they wouldn't do it (Student Questionnaire. $5: 242$ )

There are groups where only one or two people work and it's not fair. The rest of them get too comfortable and their work is minimal. I would try watching those who do not work, or not giving them the same grade (Student Questionnaire. 5:123)

When the members of the group do not work, the project can be a disaster; and if a person does not want to do their job then discussions arise; for me the experience is negative because I did work and I did it all by myself (Student Questionnaire. 6:134)

With regard to the second objective of the study, knowing how the formative evaluation process develops in the operational dynamics of the PBL, taking into account the teachers involved in the inclusion of PBL in their teaching practice, it seems to show a difficult development, recognizing the constant presence of tests and evaluations as a generalized tool of measurement of the acquired knowledge. However, it recognizes the value of other competence aspects that must necessarily be considered by applying tools that make it easier for students to raise awareness of the developed learnings, as well as the value of the teacher as a guide who oversees the learning process and controls and leads it.

Evaluation is a complex topic because if you base your work on projects and in the end you give them an exam you are giving more value to the contents and not so much to everything else; that is why for the final evaluation we are already working on taking into consideration the valuable opinions of each one, that of the classmates, the ones shared among students and teachers through auto evaluation practices, co-evaluation and heteroevaluation. In this way they develop their critical ability, their capability to value themselves and others (Male Teacher Interview. 4:323).

I like as a teacher to supervise how they perform the practice of $\mathrm{PBL}$, if everyone works and contributes; then I believe that this work is done in front of them (Male teacher interview. 4:442).

When one works in a group within the classroom the relationship between the students and the teacher is reinforced because they are no longer seen as a figure of authority or a superior, but as a guide who knows, who helps, who collaborates with them and listens to them (Female Teacher Interview. 4:388).

The same teacher in her reflexive diary mentions the use of evaluation practices such as co-evaluation allowing the students to express themselves in order to participate and getting them involved through paper presentations and consequent evaluation between classmates; she also references the heteroevaluation allowing the time for student-teacher dialog based on the assignments and a proposal to solve the project addressed.

What I want is for them to work a little bit and, to make sure of that, as they develop the eight sections on their project, they must make a presentation in front of the rest of their classmates that will be evaluated by themselves and commented by the rest of us (Reflexive Diary. 3:701). 
Once the presentations were completed, I gave each group a questionnaire to conduct a co-evaluation on the project addressed; for this evaluation, each group would evaluate the work presented by the other groups, grading representatively each of the sections of the project, so that we could have several grades to be used for the final evaluation of the project (Reflexive Diary. 3:335).

To conclude, the students recognize certain limitations in the evaluation of their work, mainly in a key of a non-follow-up of the process established in the classroom to address the project and the assignments required. They propose solutions to develop a greater control on those people in the group who do not contribute in the realization of the aforementioned assignments, as well as a better management of the final grade that, being the same for the whole group, is detrimental, in their perception, to the formation of a fair value in relation to the unequal effort made. Sometimes the proposed solutions are oriented in an opposite direction to the cooperative spirit that the $\mathrm{PBL}$ promotes.

The way I would solve the problem of those colleagues who take advantage of the work of others when working as a group is to set them alone to work; to do their own project; that way, at least they would control those who do not work (Student Questionnaire. 5:168).

As a positive experience, I find working with projects more enjoyable and entertaining; the most negative thing is that it is almost never worked equally, and approximately the same grade is received. It is better to grade individually instead of having a final group grade (Student Questionnaire. 3:356).

The problem with those classmates who take advantage of other's work when working in a group I would solve by telling the teacher, and giving an individual grade on each assignment done by each group member, specifying who did what (Student Questionnaire. 5:206).

\section{Discussion}

When teaching methods such as PBL are used, in which the teacher poses a question, a challenge or a specific problem connected with the reality that students have to solve (Bell, 2010), the degree of involvement of these students seems to increase. In the teaching-learning process, they become the protagonists when they are invited to seek, assess, interpret and share information with the rest of the group members, and they apply a more critical way of thinking, since they are constantly and mutually questioned about why and what are they studying for.

In this sense, the students participate collaboratively in all the proposed assignments: understanding and interpretation of data, collection of information, preparation of partial deliveries, writing of the final report, and oral presentation before others, assessing the problem or challenge proposed with the intention of being able to draw their own conclusions.

In the implementation of these formative dynamics as an alternative to more traditional methodological models, a new way of generating and developing learning is consequently activated, applying a cooperative work model, being the management of group activity to face the project a vital aspect.

In relation to the cooperative dynamics of operation of the PBL experiences developed, the implementation of a methodological model is observed; this model is based, as a starting point, on cooperative structures by which the students are intended to address the project. Such structures materialize in the form of small and heterogeneous groups that seek to guarantee communication between their members (Johnson et al., 1999a), unleashing a strongly competency learning model (Perrenoud, 2008) in which students have to combine the knowledge, skills and attitudes that they learn, in a shared way with their classmates, to face the assignments and carry out the project proposed and presented by the teacher (Bell, 2010; Thomas, 2000).

In the same way, intentionally, the dynamics proposed by teachers through this methodology intend to trigger learning situations in which negotiation, compromise, listening, agreement-reaching and coordination to make decisions and solve problems are aspects of interaction and socialization necessarily to be encouraged, as established by Belland et al. (2006) and Bender (2012).

However, there is a general concern about the management in the classroom of the cooperative structures placed in order to develop the project. Friction, conflicts inherent in group life and the consequence of the cooperation dynamics applied to establish in a shared way the action plan to address the entrusted project are recognized. They identify in certain students a lack of willingness for cooperation and commitment, aspects that generate intragroup tension that for Slavin (2014) is necessary to keep track of by the teacher during the learning process, for example, paying special attention to those situations in which the stowaway effect occurs (Kerr and Bruun, 1983; Slavin, 2014).

In this matter, the students themselves describe occasional imbalances in the efforts made to carry out the assignments, the weight of the workloads assumed and, ultimately, a certain lack of harmony when relating to each other when it comes to getting involved in the project. For Del Canto et al. (2009), Jhen and Mannix (2001), Putnam (1997), and Velázquez (2013) cooperation requires attention on these critical aspects during its development, benefiting the group climate itself and thus, the performance on the assignments. For Gámez and Torres (2012) and McConnell (2005), intragroup conflict provokes generalized complaints, loss of enthusiasm and motivation for group members, a source of arguments and frustration, an aspect present in the study in the voice of the students involved.

At the same time, the teaching staff, in relation to the evaluation of the formative dynamics based on the PBL put in place, recognize the importance of paying attention to various competency aspects inherent to the cooperative learning process obtained.

This aspect, in line with what is suggested by Blank (1997), Dickinson et al. (1998), Mergendoller et al. (2006) and Belland et al. (2006), materializes in the attention to capacities such as empathy, listening, critical thinking, collaboration, decisionmaking, group responsibility, the teacher assuming a role of leader and guide of all these during the process of learning, as considered by Thomas (2000), Walberg and Paik (2002) and Kokotsaki et al. (2016), supporting the maintenance of a more motivating, participatory and facilitating group work climate (Lima et al., 2007).

Despite the use of traditional evaluation dynamics presenting a more finalist nature, such as the test or exam, the teaching staff recognize the value of formative and shared evaluation tools, such as self-evaluation, co-evaluation and heteroevaluation. In this sense, it is observed in the group, not without difficulties (Ertmer and Simons, 2005) a certain appreciation for the involvement of the students in the evaluation process, giving them a voice to express their own perception through dynamics such as the presentation of resulting works and shared evaluation in this regard. Paradoxically, the students involved consider a certain lack of follow-up by the teachers on the assignments they carry out and that are a part of the project, in correlation with a conflictive management of the grade in this regard. For Pérez-Pueyo 
and López-Pastor (2017) it is necessary to take further steps in the autonomy and personal initiative of the students and their involvement in the evaluation process, the teacher being able to apply techniques such as auto-evaluation, peer evaluation, shared evaluation, self-grading and dialogued grading. The same authors, for example, advocate for intervening in a Secondary Education classroom by applying cooperative projects and final presentations of group papers or events preparation, tutoring in a shared way with their students and involving them in their-and other's -learning process; The teacher can also complete the methodological initiative by developing group auto-evaluations and coevaluations, the students evaluating the process of effecting the group assignments or the actual completion of the final presentations. Some recommended instruments to lead the aforementioned evaluation techniques are the group class diary, the auto-evaluation reports and the evaluation scales (Hamodi et al., 2015; Hernando et al., 2017).

In short, the $\mathrm{PBL}$ experience carried out contains all the technical elements to facilitate a learning model of the competence type, which addresses both knowledge and skills to carry out the assignments and to offer solutions to the problems inherent to the given project, as well as the abilities to do so jointly and cooperatively. However, it shows that the methodological practice proposed still suffers from a real follow-up on the group process set, establishing feedback means in the action itself, neglecting the potential conflicts that arise and the smooth completion of the assignments.

In relation to evaluation, the importance of a more formative evaluation model is recognized among the teachers involved, appreciating practices that activate the participation and involvement of students, although the weight of the final products continues to be relevant to the process itself.

\section{Data availability}

All data generated or analyzed during this study are included in this published article.

Received: 22 September 2020; Accepted: 5 November 2020; Published online: 08 December 2020

\section{References}

Barret T (2005) What is problem-based learning. In: O'Neill G, Moore S, McMullin B (eds) Emerging issues in the practice of university learning and teaching. AISHE, Dublin, pp. 55-66

Bell S (2010) Project-based learning for the 21st century: skills for the future. Clear House 83:39-43. https://doi.org/10.1080/00098650903505415

Belland BR, Ertmer PA, Simons KD (2006) Perceptions of the value of problembased learning among student with special needs and their teachers. Int J Problem-based Learn 1(2):1-18. https://doi.org/10.7771/1541-5015.1024

Bender W (2012) Project-based learning: differentiating instruction for the 21st Century. Corwin, California

Blank W (1997) Authentic instruction. In: Blank WE, Harwell S (eds.) Promising practices for connecting high school to the real World. University of South Florida, Tampa, pp. 15-21

Blumenfeld PC, Soloway E, Marx R (1991) Motivating Project-based learning: sustaining the doing, supporting the learning. Educ Psychol 26:369-398. https://doi.org/10.1080/00461520.1991.9653139

Brown S (2015) Authentic assessment: using assessment to help students learn. Electr J Educ Res Assess Eval 21(2):1-8. https://doi.org/10.7203/ relieve.21.2.7674

Brown S, Race P (2013) Using effective assessment to promote learning. In: Hunt L, Chalmers D (eds.) University teaching in focus. A learning-centred approach. Routledge, London, pp. 74-91

Brundiers K, Wiek A (2013) Do we teach what we preach? An international comparative appraisal of problem- and project-based learning courses in sustainability. Sustainability 5(4):1725-1746. https://doi.org/10.3390/su5041725
Burdett J (2007) Degrees of separation balancing intervention and independence in group work assignments. Aust Educ Res 34(1):55-71. https://doi.org/10.1007/ BF03216850

Del Canto P, Gallego I, López JM, Mora J, Reyes A, Rodríguez E, Valero M (2009) Conflictos en el trabajo en grupo: cuatro casos habituales. Revista de Formación e Innovación Educativa Universitaria 2(4):344-359

Díaz-Barriga F, Hernández R (2002) Estrategias docentes para un aprendizaje significativo. McGraw-Hill, Barcelona

Dickinson KP, Soukamneuth S, Yu HC, Kimball M, D'Amico R, Perry R, Kingsley C, Curan SP (1998) Providing educational services in the Summer Youth Employment and Training Program [Technical assistance guide]. U.S. Department of Labor, Office of Policy and Research, Washington

Dyson B (2002) The implementation of cooperative learning in an elementary school physical education program. J Teach Phys Educ 22(1):69-85

Ertmer PA, Simons KD (2005) Scaffolding teachers' efforts to implement problem based learning. Int J Learn 12(4):319-328. https://doi.org/10.18848/14479494/CGP/v12i04/46447

Flick U (2007) El diseño de investigación cualitativa. Morata, Madrid

Gámez MJ, Torres C (2012) Las técnicas de grupo como estrategia metodológica en la adquisición de la competencia de trabajo en equipo de los alumnos universitarios. J Educ Teach Train 4:14-25

García I, Gros B, Noguera I (2010) La relación entre las prestaciones tecnológicas y el diseño de las actividades de aprendizaje para la construcción colaborativa del conocimiento. Cultura y Educación 22(4):395-418. https://doi.org/ $10.1174 / 113564010793351867$

Hamodi C, López-Pastor V, López-Pastor AT (2015) Medios, técnicas e instrumentos de evaluación formativa y compartida del aprendizaje en educación superior. Perfiles Educativos 37(147):146-161

Hernández March A (2006) Metodologías activas para la formación de competencias. Educatio Siglo XXI 24:35-56

Hernando A, Hortigüela D, Pérez-Pueyo A (2017) El proceso de evaluación formativa en la realización de un video tutorial de estiramientos en inglés en un centro bilingüe. In: López-Pastor V, Pérez-Pueyo A (eds) Buenas prácticas docentes: Evaluación formativa y compartida en educación: experiencias de éxito en todas las etapas educativas. Universidad de León, León, pp. 260-271

Jhen KA, Mannix EA (2001) The dynamic nature of conflict: a longitudinal study of intragroup conflict and group performance. Acad Manag J 44(2):238-251. https://www.jstor.org/stable/3069453

Johnson D, Johnson R (1999) Aprender juntos y solos. Aprendizaje cooperative, competitivo e individualista. Aique, Buenos Aires

Johnson D, Johnson R, Holubec E (1999a) El aprendizaje cooperativo en el aula. Paidós, Buenos Aires

Johnson D, Johnson R, Holubec E (1999b) Los círculos del aprendizaje. La cooperación en el aula y la escuela. Aique, Buenos Aires

Jonassen D (2011) Supporting problem solving in PBL. Interdiscip J ProblemBased Learn 5(2):95-119. https://doi.org/10.7771/1541-5015.1256

Kagan S (2000) L'apprendimento cooperativo: L'approccio strutturale. Edizioni Lavoro, Roma

Kalpokaite N, Radivojevic I (2019) Demystifying qualitative data analysis for novice qualitative researchers. Qual Rep 24(13):44-57

Kerr NL, Bruun SE (1983) Dispensability of member effort and group motivation losses: free-rider effects. J Pers Soc Psychol 44(1):78-94. https://doi.org/ 10.1037/0022-3514.44.1.78

Kokotsaki D, Menzies V, Wiggins A (2016) Project-based learning: a review of the literature. Improving Schools 19(3):267-277. https://doi.org/10.1177/ 1365480216659733

Kolmos A (2012) Changing the curriculum to problem based and project-based learning. In: Yusof KM, Azli NA, Kosnin AM, Syed Yusof SK, Yusof YM (eds) Outcome-based science, technology, engineering, and mathematics education: innovative practices. IGI Global, pp. 50-61

Krajcik JS, Blumenfeld PC (2006) Project-based learning. In: Sawyer K (ed) Cambridge handbook of the learning sciences. Cambridge University Press, pp. 317-334

Lima RM, Carvalho D, Flores M, Van Hattum-Janssen N (2007) A case study on project led education in engineering: student's and teacher's perceptions. Eur J Eng Educ 32(3):337-347

Lincoln YS, Guba EG (1985) Naturalistic inquiry. Sage, Beverly Hills

Martín A, Rodríguez S (2015) Motivación en alumnos de Primaria en aulas con metodologías basadas en proyectos. Revista de Estudios e Investigación en Psicología y Educación Extr 1:58-62. https://doi.org/10.17979/ reipe.2015.0.01.314

McConnell D (2005) Networked e-learning groups. Stud High Educ 30(1):25-42. https://doi.org/10.1080/0307507052000307777

Mergendoller JR, Maxwell NL, Bellisimo Y (2006) The effectiveness of problembased instruction: a comparative study of instructional methods and student characteristics. Interdiscip J Problem-Based Learn 1(2):49-69. https://doi.org/ 10.7771/1541-5015.1026 
Miles MB, Huberman AM, Saldaña J (2014) Qualitative data analysis. A methods sourcebook. Sage, London

Neal JW, Neal ZP, VanDyke E, Kornbluh M (2015) Expediting the analysis of qualitativedata in evaluation: a procedure for the rapid identification of themes fromaudio recordings (RITA). Am J Eval 36(1):118-132. https://doi. org/10.1177/1098214014536601

Orlick T (1986) Juegos y deportes cooperativos. Editorial Popular, Madrid

Pérez-Pueyo A, López-Pastor V (2017) El estilo actitudinal como propuesta metodológica vinculada a la evaluación formativa. In: López-Pastor V, PérezPueyo A (eds) Evaluación formativa y compartida en educación: experiencias de éxito en todas las etapas educativas. Universidad de León, Secretariado de Publicaciones, León, pp. 240-259

Perrenoud P (2008) Construir las competencias, ¿es darle la espalda a los saberes? Revista de Docencia Universitaria 6(11):1-8

Prince MJ, Felder M (2006) Inductive teaching and learning methods: definitions, comparisons and research bases. J Eng Educ 95(2):123-138. https://doi.org/ 10.1002/j.2168-9830.2006.tb00884.x

Pujolàs P (2009) La calidad en los equipos de aprendizaje cooperativo. Algunas consideraciones para el cálculo del grado de cooperatividad. Revista de Educación 349:225-239

Putnam J (1997) Cooperative learning in diverse classrooms. Prentice-Hall, Upper Saddle River, NJ

Sánchez N (2018) Clase invertida y aprendizaje basado en proyectos en el aula de biología. Un proyecto de innovación para $1^{\circ}$ de la ESO. Valoración de la experiencia. Enseñanza Teaching 36(1):81-11. https://doi.org/10.14201/ et21836181110

Slavin RE (2014) Cooperative learning and academic achievement: why does groupwork work? Anales de Psicología 30(3):785-791. https://doi.org/ 10.6018/analesps.30.3.201201

Thomas JW (2000) A review of research in project-based learning. Autodesk Foundation, San Rafael, CA

Velázquez C (2013) La pedagogía de la cooperación en educación física. Kínesis, Armenia

Walberg H, Paik S (2002) Prácticas eficaces. Magisterio, Bogotá

\section{Acknowledgements}

We gratefully acknowledge the support of the teachers, school managers and the children that participated for their collaboration.

\section{Author contributions}

The authors contributed equally to this work.

\section{Competing interests}

The authors declare no competing interests.

\section{Additional information}

Correspondence and requests for materials should be addressed to B.d.I.T.-N

Reprints and permission information is available at http://www.nature.com/reprints

Publisher's note Springer Nature remains neutral with regard to jurisdictional claims in published maps and institutional affiliations.

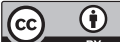

Open Access This article is licensed under a Creative Commons Attribution 4.0 International License, which permits use, sharing, adaptation, distribution and reproduction in any medium or format, as long as you give appropriate credit to the original author(s) and the source, provide a link to the Creative Commons license, and indicate if changes were made. The images or other third party material in this article are included in the article's Creative Commons license, unless indicated otherwise in a credit line to the material. If material is not included in the article's Creative Commons license and your intended use is not permitted by statutory regulation or exceeds the permitted use, you will need to obtain permission directly from the copyright holder. To view a copy of this license, visit http://creativecommons.org/ licenses/by/4.0/.

(C) The Author(s) 2020 